\title{
ARTYKUEY
}

Jacek Soszyński

Warszawa

\section{Od synchronizacji do wizualizacji Prezentacja dziejów na kartach średniowiecznych kronik uniwersalnych}

Kroniki $^{1}$ uniwersalne, przedoświeceniowe kompendia historii powszechnej ${ }^{2}$, pełniły w świecie średniowiecznej kultury intelektualnej rozliczne funkcje, pośród których niepoślednie miejsce zajmowało kształcenie świadomości historycznej. Świadomość ta opiera się na wielu czynnikach warunkowanych przez tradycje natury ustnej, piśmiennej, obrazowej i rzeczowej ${ }^{3}$. Kroniki uniwersalne dostarczały niezbędnego tła ogólnego o kapitalnym zupełnie znaczeniu dla orientacji w otaczającym

${ }^{1}$ Pierwotna wersja tego artykułu została przedstawiona na konferencji „Wizualizacja wiedzy. Od Biblia pauperum do hipertekstu” (Warszawa, 2010). Niestety, autor nie zdążył dostarczyć wykończonego tekstu swego wystąpienia w terminie umożliwiającym jego włączenie do tomu zbierającego dorobek spotkania, za co czuje sie w obowiązku raz jeszcze organizatorów przeprosić.

${ }^{2}$ Co się tyczy gatunku kronik uniwersalnych por.: K. H. Krüger, Die Universalchroniken, Turnhout 1976, Anna-Dorothee von den Brincken, Studien zur lateinischen Weltchronistik bis in das Zeitalter Ottos von Freising, Düsseldorf 1957 oraz artykuł tejże Abendländisches Mittelalter, [w:] Mensch und Weltgeschichte. Zur Geschichte der Universalgeschichtschreibung, hrsg. A. Randa, Salzburg 1969, 43-58, a także J. Soszyński, Sacerdotium - imperium - studium. Wtadze uniwersalne w późnośredniowiecznych kronikach martyniańskich, Warszawa 2006, s. 13.

${ }^{3}$ Literatura traktująca o średniowiecznej świadomości historycznej jest ogromna a wyczerpujące jej wyliczenie wymagałoby odrębnej publikacji o charakterze bibliograficznym. Dlatego też ograniczam się do przytoczenia kilku ważniejszych publikacji, traktujących o bardzo różnych aspektach tego zjawiska, gdzie czytelnik odnajdzie dalsze wskazówki co do literatury przedmiotu: Bernard Guenée, Histoire et culture historique dans l'occident médiéval, Paris 1980; F. Graus, Funktionen der spätmittelalterlichen Geschichtsschreibung, [w:] Geschichtsschreibung und Geschichtsvewußtsein in späten Mittelalter, hg. von H. Patze, Sigmaringen 1987, s. 11-55; J. Assmann, Das kulturelle Gedächtnis. Schrift, Erinnerung und politische Identität in frühen Hochkulturen, 1992, s. 48-59; Heike Johanna Mierau, Antje Sander-Berke, Birgit Studt, Studien zur Überlieferung der Flores temporum, „Monumenta Germaniae Historica. Studien und Texte”, Bd 14, Hannover 1996, s. 8-12; B. Zientara, Świt narodów europejskich, Warszawa 1985. 
świecie - pouczały czytelnika nie tylko, co się wydarzyło w przeszłości bliskiej, dalszej i tej najodleglejszej, lecz także jak należy rozumieć całość procesu dziejowego, podsuwając jednocześnie sugestię, czego się należy spodziewać w przyszłości. Wśród badaczy na ogół panuje przekonanie, że oddziaływanie kronik uniwersalnych mieści się bez reszty w piśmiennej tradycji przekazu historycznego. Tymczasem gatunek ten od chwili swego powstania w późnej starożytności w sposób świadomy odwoływał się także do aspektu obrazowego ${ }^{4}$. Celem niniejszego artykułu jest przyjrzenie się wykorzystaniu graficznego rozplanowania tekstu na przykładzie trzech, zapewne najbardziej popularnych, przedstawicieli przywołanego gatunku, powstanie których na dodatek oddzielają całe stulecia: pracom Euzebiusza-Hieronima, Marcina Polaka i Wernera Rolevincka.

Świadome posługiwanie się przestrzenią rozkładówki książkowej, obejmujące rozplanowanie paralelnych kolumn wykorzystujących równolegle przekaz tekstowy i liczbowy, uchodzi od lat za standardowy elementy sztuki drukarskiej, a pojawienie się składu cyfrowego umożliwiło tworzenie jeszcze bardziej wymyślnych schematów kompozycyjnych. Do tradycyjnych tabel dodano tzw. „kapsułki” z tekstem, różnorodnie osadzane ilustracje, a przede wszystkim wprowadzono wspaniałe efekty kolorystyczne. Rozkładówka książki przemawia więc do czytelnika nie tylko treścią lecz także wszechstronnym opracowaniem graficznym. Owe zachwycające niekiedy swą pomysłowością koncepcje graficzne mają jednak bardzo stary rodowód, starszy niż sama książka kodeksowa. Przykłady tworzenia spisów i tabel odnajdujemy już wśród najstarszych zachowanych przykładów pisma ${ }^{5}$. Nic więc dziwnego, że wraz $\mathrm{z}$ upowszechnianiem się formy książki kodeksowej tabele zawitały również na jej kartach; więcej, ta nowa forma książki pozwoliła na nowe ciekawe rozwiązania. Rozkładówka kodeksowa, w przeciwieństwie do pojedynczej kolumny pisma w zwoju, dostarczyła dostatecznie dużej powierzch-

\footnotetext{
${ }^{4} \mathrm{Na}$ rolę czynnika obrazowego w kronikarstwie uwagę zwracali przede wszystkim badacze niemieccy, m.in.: Monika Zimmermann, Die Synopse als Mittel universalhistorischer Orientirung, Göttingen-Frankfurt-Zürich 1977; Gert Melville, Geschichte in graphischer Gestalt: Beobachtungen zu Einer spätmittelalterlichen Darstellungsweise, [w:] Geschichtsschreibung und Geschitsbewusstsein im Späten Mittelalter, ed. H. Patze, Sigmaringen 1987, s. 57-154, A.-D. von den Brincken, In una pagina ponendo pontifices in alia pagina imperatores. Das Kopieren der Tabellarischen Papst-Kaiser-Chronik des Martin von Troppau OP (†1278), „Revue d'Histoire des Textes”, 18:1988, s. 109-135; Benjamin Steiner, Die Ordnung der Geschichte: Historische Tabellenwerke in der Frühen Neuzeit, Köln-Weimar-Wien 2008, s. 8-48.

${ }^{5}$ Por. B. Steiner, Die Ordnung der Geschichte..., s. 8-11.
} 
ni dla bardziej rozwiniętych pomysłów graficznych. Bliższą uwagę na zjawisko to skierowało dwoje badaczy amerykańskich, Anthony Grafton i Megan Williams, których zainteresował fakt, iż dwa wielkie dzieła leżące u podstaw chrześcijańskiej nauki późnej starożytności - Hexapla Orygenesa i kronika uniwersalna Euzebiusza z Cezarei - posługują się w sposób celowy i przemyślany wielokolumnowym układem tekstu, umożliwiającym czytelnikowi nie tylko lekturę, lecz także krytyczne studia nad przyswajanym materiałem ${ }^{6}$. O ile problem Hexapli i jej wpływu na rozwój studiów biblijnych w czasach schyłkowego antyku i wczesnego średniowiecza pozostaje poza zainteresowaniem niniejszego artykułu, o tyle rola rozplanowania graficznego dzieła Euzebiusza z Cezarei w ugruntowaniu formy kronik uniwersalnych jest trudna do przecenienia. Przez całe średniowiecze spora część autorów uprawiających interesujący nas gatunek historyczno-literacki wzorem Euzebiusza sięgała po możliwości, jakie dawało paralelne organizowanie treści. Celem uchwycenia najważniejszych przejawów tych technik porównajmy sposób w jaki je wykorzystują wyżej wspomniani autorzy: Hieronim ze Strydonu, który udostępnił światu łacińskojęzycznemu kronikę Euzebiusza z Cezarei (IV w.), Marcin Polak (XIII w.) i Werner Rolewinck (XV w.). Dzieli ich nie tylko przepaść stuleci, która w przypadku dwóch ostatnich pisarzy nie wydaje się aż tak wielka, lecz także fakt, że dwie pierwsze kroniki wypełniały swe zadania podlegając transmisji rękopiśmiennej, trzecia zaś od początku funkcjonowała przede wszystkim w postaci drukowanej. Wszystkie trzy łączy natomiast wielka popularność, a zatem również stopień oddziaływania na współczesnych i potomnych.

\section{Euzebiusz z Cezarei i Hieronim ze Strydonu}

Kronika Euzebiusza z Cezarei w średniowiecznej kulturze zachodniej funkcjonowała pod postacią tłumaczenia dokonanego przez św. Hieronima. Przekład ów, choć w stosunku do oryginału cechuje się pewnymi różnicami, w zasadzie powinien być określany jako „Kronika Euzebiusza-Hieronima". Termin ten niekiedy spotyka się w literaturze historycznej ale najczęściej badacze odnoszą się do tego tekstu zgodnie z tradycją średniowieczną, nazywając go „Kroniką Hieronima”. Mimo

${ }^{6}$ A. Grafton, M. Williams, Christianity and the Transformation of the Book: Origen, Eusebius, and the Library of Caesarea, Cambridge, Massachusetts - London, England 2006. 
to, faktycznym twórcą rozplanowania graficznego rozkładówki - tego, co nas w Kronice Hieronima w niniejszym artykule interesuje najbardziej - był Euzebiusz z Cezarei. Jemu więc należy poświęcić najpierw uwagę.

Wczesne lata Euzebiusza są słabo oświetlone przez źródła ${ }^{7}$. Urodził się w początkach lat sześćdziesiątych III wieku, zapewne w Cezarei Palestyńskiej, z którym to miastem związany był zresztą do końca życia. Odebrał staranne wykształcenie; władał kilkoma językami: greką, łaciną, hebrajskim i aramejskim. Jego mistrzem był późniejszy męczennik Pamfilos, który z kolei był uczniem Pireiosa, wykształconego przez Orygenesa. Pamfilos czuł się spadkobiercą duchowym Orygenesa i w Cezarei kontynuował tradycję badań biblijnych w duchu swego wielkiego poprzednika; owo poczucie łączności z mędrcem aleksandryjskim przekazał również swemu podopiecznemu. Euzebiusz za zachętą Pamfilosa założył w Cezarei szkołę chrześcijańską, która stała na wysokim poziomie. Pracował również naukowo, zaskarbiając sobie szacunek wśród mieszkańców miasta. W trakcie ostatnich prześladowań chrześcijan opuścił Cezareę i schronił się w Egipcie. Prawdopodobnie dosięgły go i tam represje ale, w przeciwieństwie do swego mistrza, mimo wszystko przeżył; niewykluczone jednak, że za cenę kompromisów z sumieniem, o co w późniejszych latach go oskarżano. Po edykcie 313 r. Euzebiusz szybko stał się postacią publiczną. Zapewne już w 314 r. wyświęcono go na biskupa Cezarei. Na stanowisku tym pozostał do końca życia, czynnie uczestnicząc w kontrowersji ariańskiej po stronie zwolenników Ariusza - arianizm wszak wywodził się z myśli Orygenesa, a Euzebiusz sam się uważał za przedstawiciela szkoły orygenistów. W 325 r. brał udział w zgromadzeniu w Nicei, które przeszło do historii pod mianem pierwszego soboru powszechnego, stojąc wśród bliskich cesarzowi Konstantynowi Wielkiemu zwolenników kompromisu. W następnych latach był bardzo czynny w życiu Kościoła, dużo podróżując i będąc częstym gościem na dworze cesarskim, gdzie cieszył się zaufaniem i autorytetem. Ostatnie lata, już po śmierci faworyzującego go Konstantyna Wielkiego (337), spędził w swej stolicy biskupiej. Zmarł 30 maja $339 \mathrm{r}$.

${ }^{7}$ Por. Euzebiusz z Cezarei Palestyńskiej [w:] Jan Maria Szymusiak, Marek Starowiejski, Stownik wczesnochrześcijańskiego piśmiennictwa, Poznań 1971 [dalej cyt.: Szymusiak, Starowiejski, Stownik...], s. 142-146; Wojciech Stawiszyński, Bibliografia patrystyczna 1901-2004. Polskie ttumaczenia tekstów starochrześcijańskich pierwszego tysiąclecia, Kraków 2005, s. 232-236. Z najnowszej literatury polskiej wymienić należy pracę Anny Kotłowskiej, Obraz dziejów w Chronici canones Euzebiusza z Cezarei, Poznań 2009, s. 43-58. 
Euzebiusz był bardzo płodnym pisarzem, podejmującym się wypowiadania na różne tematy, a jego spuścizna daleka jest od stanu zadowalającego opracowania ${ }^{8}$. Spośród utworów odnoszących się do historii wyróżniają się trzy: Historia kościelna ${ }^{9}$, przełożona w początkach $\mathrm{V}$ w. na łacinę przez Rufina z Akwilei; panegiryczne Życie Konstantyna ${ }^{10}$ oraz Kronika ${ }^{11}$. Nie wolno jednak zapominać, że nie były one osamotnione.

Ukończona jeszcze przed soborem w Nicei (325) Kronika Euzebiusza, w oryginale greckim zachowała się w postaci niewielkich fragmentów. Dysponujemy jednak jej przekładami: łacińskim, armeńskim i arabskim, z których żaden co prawda nie jest kompletny, ale potraktowane wspólnie pozwalają na dosyć wierne zrekonstruowanie treści orygina$\mathrm{lu}^{12}$. Owa rekonstrukcja odsłoniła nam dzieło wielce nietypowe. W swej pierwotnej postaci Kronika Euzebiusza składała się z dwóch ksiąg. Pierwsza z nich miała charakter narracyjny. Autor przedstawia w niej wyniki krytycznego porównania dzieł należących do różnych tradycji historiograficznych. Dyskutuje problemy chronologii dziejów i następstwa postaci historycznych, podając niekiedy w wątpliwość wiarygodność przekazów. Porównuje również różne tradycje tekstowe Starego Testamentu i wykrywa między nimi niespójności chronologiczne. Krytyka owych problemów prowadzi go do wniosku, że Septuaginta jest najbardziej wiarygodną wersją Pisma świętego. Pierwsza księga Kroniki Euzebiusza jest więc nie tyle pracą historiograficzną, co metodologicznym wstępem do właściwej historii ludzkości, którą stanowi część druga Kroniki. Część druga także nie jest typową opowieścią o czasach minionych: miast narracji zawiera potężny zestaw skomplikowanych, wielowątkowych tablic synchronistycznych.

Hieronim, urodzony ok. 345 r. w Strydonie w prowincji Dalmacja, to jeden z najważniejszych autorów wczesnochrześcijańskich. W trakcie

${ }^{8}$ A. Kotłowska, Obraz dziejów..., s. 58.

${ }^{9}$ Por. M. Geerard, Clavis Patrum Graecorum, t. 1-5, Brepols - Tournhout 1974-1998 (dalej cyt.: CPG), nr 3495. Euzebiusz z Cezarei, Historia kościelna. O męczennikach palestyńskich, z greckiego tłumaczył, zaopatrzył wstępem, objaśnieniami, skorowidzami ks. Arkadiusz Lisiecki, Poznań 1924 (Pisma Ojców Kościoła, 3).

${ }^{10}$ CPG 3496. Euzebiusz z Cezarei, Życie Konstantyna, wstęp, tłumaczenie, przypisy: Teresa Wnętrzak, Kraków 2007 (Źródła Myśli Teologicznej, 44).

${ }^{11}$ CPG 3494. Jak dotychczas nie powstał polski przekład kroniki Euzebiusza, W. Stawiszyński, dz. cyt., odnotowuje tylko tłumaczenia fragmentów (s. 233).

${ }^{12}$ Die Chronik aus dem Armenischen übersetzt mit textkritischen Commentar, hrsg. von Josef Karst, Leipzig 1911 (Die grechischen christlichen Schriftsteller der ersten drei Jahrhunderte, 20: Eusebius Werke, Bd. 5). Dzieje badań nad kroniką, jej tradycje językowe i charakterystykę przedstawia A. Kotłowska (Obraz dziejów..., s. 9-42, 109-172). Jednak książka tej autorki, z uwagi na niedopracowanie redakcyjne, jest bardzo trudna w percepcji. 
swego długiego życia (zm. 420) działał w Italii, Galii, Azji Mniejszej, Syrii, Egipcie i Palestynie ${ }^{13}$. Oprócz swych najsłynniejszych przekładów biblijnych, był także autorem licznych pism o charakterze egzegetycznym, dogmatycznym i historycznym; pozostawił również obfitą korespondencję ${ }^{14}$. Prace nad przekładem Kroniki Euzebiusza i własnym jej uzupełnieniem ukończył ok. 380 r. Powstała pod jego piórem kronika uniwersalna, czyli Kronika Euzebiusza-Hieronima, nie jest prostym odzwierciedleniem dzieła Euzebiusza. Najważniejsze różnice skupiają się w dwóch zasadniczych punktach: Hieronim pominął całkowicie Euzebiuszową księgę pierwszą oraz uzupełnił całość o kontynuację sięgającą roku $379^{15}$.

Nie ma powodów, by domniemywać, że Hieronim zmodyfikował rozplanowanie graficzne treści zaprojektowane przez Euzebiusza. Zaproponowany układ porządkuje upływ czasu w pionie, w poziomie zaś prezentując wydarzenia współczesne - jest to klasyczna postać tablicy synchronistycznej ${ }^{16}$. Początkiem rachunku czasu są narodziny Abrahama zsynchronizowane z 43 rokiem panowania Ninusa w Asyrii, 22 panowania Europsa w Sikionie i przewagą dynastii tebańskiej w Egipcie. W tablicy wyróżnione jest 22 różnych cywilizacji ukazanych w postaci wątków (tzw. fila regnorum) ciągnących się w różnych zestawieniach w pionie przez kolejne tablice. Należą do nich przykładowo: Asyria, Hebrajczycy, Egipt, Sykion, Ateny, Syria, Rzym itp. Żadne z fila regnorum nie ciągnie się przez całość zestawienia. Cywilizacje pojawiają się i znikają z areny dziejowej; zawsze w związku z ważnym wydarzeniem historycznym: założeniem dynastii albo upadkiem królestwa. Liczba ciągnionych wątków nie jest stała, dochodząc w przypadku największego zagęszczenia tablicy do dziewięciu. Rola danej cywilizacji w historii była uwidoczniona jej umiejscowieniem względem lewego marginesu tablicy, im bliżej tym

${ }^{13}$ Szymusiak, Starowiejski, Stownik..., s. 187-191; W. Stawiszyński, Bibliografia patrystyczna 1901-2004. Polskie tłumaczenia tekstów starochrześcijańskich pierwszego tysiaclecia, Kraków 2005, s. 284-301.

14 Tamże.

15 Istnieje szereg nowożytnych wydań drukowanych kroniki Hieronima, z których ostatnie opublikował w 1913 r. Rudolf Helm: Eusebius Werke, Bd. 7: Die Chronik des Hieronimus, hrsg. und in 2. Aufl. bearb. von R. Helm, 3. unveränderte Aufl. mit einer Vorbemerkung von Ursula Treu, Berlin 1984. Komentowany przekład Hieronimowego uzupełnienia Chronici canones ogłosił Malcolm Drew Donalson (A Translation of Jerome's Chronicon with Historical Commentary, New York 1996). Pomocne jest także dostępne w internecie popularne wydanie łacińsko-angielskie, przygotowane przez zespół koordynowany przez Rogera Pearse'a - http://www.ccel.org/ccel/pearse/morefathers/files/jerome_chronicle_00_eintro.htm [dostęp 12 grudnia 2011].

${ }^{16}$ Bliższą analizę prze-dstawia A. Kotłowska, Obraz dziejów..., s. 115-143. 
większa, zgodnie z przyjętym porządkiem translatio imperii ${ }^{17}$. Podstawowymi, choć nie jedynymi, systemami liczenia lat są: upływ czasu od narodzin Abrahama i kolejne olimpiady. W tak pomyślanym schemacie dziejowym umiejscowione zostały poszczególne wydarzenia ${ }^{18}$.

Kronika Euzebiusza-Hieronima osiągnęła sporą popularność; jej tradycja rękopiśmienna liczy dziś około stu zachowanych rękopisów, z których najstarszy datowany jest na V wiek. Przekazane w niej treści i uporządkowanie chronologiczne posłużyły za fundament łacińskiej historiografii zachodniej, a także przeniknęły do innych prac, nie tylko tych o charakterze historiograficznym. Co więcej, układ tablicy synchronistycznej stał się wzorcem dla licznych późniejszych kronik uniwersalnych, a nawet posłużył za podstawę średniowiecznego rozróżnienia dwóch gatunków kronikarstwa: historiografii i chronografii, z których pierwszy miał wszechstronnie opisywać określone zagadnienie historyczne, drugi zaś zestawiać wydarzenia sobie współczesne, porządkując ich następstwo chronologiczne ${ }^{19}$.

\section{Marcin Polak z Opawy}

Kolejny z bohaterów niniejszego artykułu - Marcin Polak z Opawy, to urodzony w początkach XIII wieku dominikanin rodem ze Śląska, który od początków lat sześćdziesiątych tego stulecia uchwytny jest źródłowo jako penitencjarz mniejszy a następnie kapelan papieski w kurii rzymskiej ${ }^{20}$. Mianowany w połowie 1278 r. arcybiskupem gnieźnieńskim, Marcin zmarł zapewne w roku następnym, w drodze na swoją stolicę i pochowany został w Bolonii. Jednak to nie działalność kościelnopolityczna przyniosła mu największą sławę. Europejski rozgłos zdobył jako autor trzech bardzo popularnych dzieł: swoistego indeksu rzeczo-

17 Por. Joseph Ward Swain, The Theory of the Four Monarchies, „Classical Philology”, 35:1940, s. 1-21.

${ }^{18}$ Charakter rozplanowania Kroniki Euzebiusza-Hieronima oddaje w pewnym zakresie jej popularne wydanie internetowe R. Pearse'a (por. wyżej, przyp. 15).

19 G. Melville, dz. cyt., s. 57.

${ }^{20}$ Co się tyczy osoby Marcina oraz jego twórczości, por. Wstęp [do:] Marcin Polak, Kronika papieży $i$ cesarzy, tekst łaciński wg wyd. Ludwiga Weilanda (MGH Scriptores, t. XII), przekład polski i komentarz: Agnieszka Fabiańska i Jacek Soszyński, Wstepp: J. Soszyński, Kęty 2008 (dalej cyt.: Marcin Polak, Kronika papieży i cesarzy...,), s. 11-84 (gdzie zestawiona jest także bibliografia). Na kwestie graficznego układu kroniki Marcina Polaka zwróciła uwagę również A.-D. von den Brincken, Martin von Troppau O.P. als Graphiker des Geschichtsablaufes, [w:] Die Anfänge des Schrifttums in Oberschlesien bis zum Frühhumanismus, hrsg. von G. Kossellek, s. 211-224. 
wego do Dekretu Gracjana i Dekretałów Grzegorza IX, podstawowych kolekcji źródeł prawa kanonicznego, zatytułowanego Margarita Decreti, zbioru kazań modelowych uporządkowanych według kalendarza liturgicznego Sermones de tempore et de sanctis, oraz najpoczytniejszej kroniki uniwersalnej późnego średniowiecza - Kroniki papieży i cesarzy, najczęściej przywoływanej po prostu jako „Kronika Marcina Polaka”21.

Ta ostatnia praca interesująca jest również z punktu widzenia wysitków nakierowanych na wykorzystanie elementów wizualizacyjnych dla przedstawienia treści intelektualnych. Marcinowa kronika powstawała przez długi czas - nie wiemy kiedy zaczął ją pisać, ale w 1268 r. pierwsza redakcja (zwana A) była już gotowa. Pracę nad kroniką kontynuował aż do śmierci, tworząc kolejne dwie redakcje (B i C), by nie wspomnieć o udostępnianych do odpisywania wersjach przejściowych $\left(\mathrm{A}^{*}\right.$ i $\mathrm{A}^{* *}$ oraz odmianki redakcji C). Pierwotny zamysł kronikarza był skromny: chodziło mu o stworzenie tablicy synchronistycznej, która miała służyć pomocą w orientacji w następstwie wydarzeń historycznych badaczom zgłębiającym tajniki rozwoju prawa kanonicznego i teologii. $\mathrm{Z}$ biegiem czasu, w drodze kolejnych uzupełnień i przebudowywania całości, tablica synchronistyczna rozrosła się do pełnej kroniki uniwersalnej, której zasadniczym celem było już nie tyle ułatwienie w „poruszaniu się” po dziejach, ile przekazanie określonego poglądu na całość historii świata, wizerunek rozwoju dziejów ludzkości rozumianych jako współistnienie dwóch komplementarnych władz: duchowej i świeckiej ${ }^{22}$. Uosobieniem tej pierwszej były dzieje papiestwa, które rozpoczynały się - zgodnie z doktryną plenitudo potestatis papae - wraz z przyjściem na świat Jezusa Chrystusa, „pierwszego i największego papieża”, i trwały w osobach kolejnych papieży. Władzę świecką personifikowała historia Imperium Romanum, kontynuowanego od $\mathrm{V}$ wieku przez cesarstwo bizantyjskie, a następnie królestwo frankijskie, na które w 800 roku, w osobie Karola Wielkiego, przeniesiona została przez papieża Leona III władza cesarska. Oba ciągi dziejowe ujęte więc były w serie biogramów papieskich i cesarskich. Ważnym elementem oddawanej przez kronikę Marcina Polaka wizji historii świata było przekonanie o wyższości władzy duchowej nad władzą świec-

${ }^{21}$ Nie ma nowoczesnej edycji krytycznej Kroniki papieży $i$ cesarzy; dysponujemy jednak wydaniem przygotowanym przez L. Weilanda (Martinus Polonus, Chronicon Pontificum et Imperatorum, Monumeta Germaniae Historica, Scriptores, 22, s. 377-475), z którego została przedrukowana ostatnia redakcja kroniki (bez aparatu krytycznego) [w:] Marcin Polak, Kronika papieży i cesarzy..., por. wyżej, przyp. 21.

22 Pogłębiona analiza tych zagadnień [w:] J. Soszyński, Sacerdotium - Imperium - Studium. Władze uniwersalne w późnośredniowiecznych kronikach martyniańskich, Warszawa 2006. 
ką, a tym samym zwierzchności papieskiej nad cesarstwem i innymi monarchami. Kronika papieży i cesarzy jest więc przykładem pracy historiograficznej podporządkowanej treściom ideologicznym i politycznym.

Aby tym skuteczniej przekazać papieską wizję dziejów, Marcin Polak posłużył się nie tylko odpowiednim doborem treści lecz także przemyślnym ich zorganizowaniem wizualnym na stronach kroniki. Stworzył tablicę synchronistyczną, przypominającą w ogólnych zarysach pomysł Euzebiusza z Cezarei, ale gruntownie zmodyfikowaną, by jednocześnie uwypuklała treści ideologiczne i, dzięki łatwości wyszukiwania materiałów, była praktyczną pomocą w pracy intelektualnej.

Kronika papieży i cesarzy w swej ostatecznej postaci dzieli się na dwie części, z których pierwsza obejmuje dzieje przedchrystusowe, druga zaś omawia historię od narodzin Chrystusa. Pierwsza część, obecna tylko w ostatniej redakcji kroniki, ma prosty układ annalistyczny, tzn. postacie i wydarzenia omawiane są według następstwa chronologicznego. Układ graficzny autor zastosował dopiero w części drugiej. Rozkładówka opracowana przez Marcina ma bardzo skomplikowaną strukturę. Przede wszystkim materia historyczna ułożona jest według porządku pionowego i poziomego. Układ poziomy rozróżnia dwie kategorie, przyporządkowane do przeciwległych stron rozkładówki: na stronach verso kronikarz umieścił wiadomości zakwalifikowane przez niego do historii władzy duchowej (sacerdotium), na stronach zaś recto - te, które uznał za przynależące do władzy świeckiej (imperium). Układ pionowy dzieli każdą rozkładówkę na pięćdziesiąt linijek, z których każdej przyporządkowany jest jeden rok. Pomyślana w ten sposób tablica synchronistyczna jest pod względem zorganizowania zawartości bardzo przejrzysta i konsekwentna, a jednocześnie nie pozwala na mnożenie treści poza mieszczące się w konkretnej ilości wierszy, ściśle określonej przez długość trwania pontyfikatu danego papieża lub panowania danego cesarza. Jak łatwo wyliczyć, czasy od narodzenia Chrystusa do drugiej połowy XIII wieku, kiedy tworzył Marcin, nie mogły przekroczyć objętości dwudziestu sześciu rozkładówek, czyli pięćdziesięciu dwóch kart. Biorąc pod uwagę, że pierwsza część kroniki liczyła w przybliżeniu od piętnastu do dwudziestu procent drugiej, całość zamykała się w sześćdziesięciu kartach, czyli pięciu regularnych składkach (seksternionach in folio) rękopiśmiennych $^{23}$.

23 Przykładowy rękopis kroniki Marcina Polaka z układem tabelarycznym jest do wglądu na stronie: http://bvpb.mcu.es/es/consulta/registro.cmd?id=396870 [dostęp 10 grudnia 2011]. 
Dokonane przez Marcina Polaka połączenie wykładu ideologii papieskiej z encyklopedycznym praktycyzmem informacyjnym okazało się niesłychanym sukcesem rynkowym. Współcześni szybko docenili zalety Kroniki papieży i cesarzy; zachowanie do dziś dzień przeszło czterystu rękopisów tego dzieła pozwala przypuszczać, że ich pierwotna liczba sięgała tysięcy egzemplarzy! Druga połowa XIII i wiek XIV to okres wielkiej popularności Marcina, a i z XV wieku nie brakuje zachowanych odpisów, jakkolwiek jego popularność wówczas już zmalała do tego stopnia, że nie uznano już za potrzebne wydać Kronike papieży i cesarzy drukiem. Renesans zainteresowań tekstem Marcina przyniosła dopiero doba reformacji, ale to już temat zupełnie inny ${ }^{24}$.

Kopiowanie tak trudnego technicznie tekstu przysparzało niemałych kłopotów. Bardzo szybko pojawiły się więc egzemplarze częściowo lub całkowicie zarzucające Marcinową wizualizację 25 . W XV w. odpisy zachowujące pierwotny układ są już rzadsze i nie jest zapewne dziełem przypadku, że jeden z nich znajdujemy pośród książek Jana z Dąbrówki (zm. 1472), profesora Uniwersytetu Krakowskiego żywo interesującego się historią, autora komentarza do Kroniki polskiej Mistrza Wincentego $^{26}$. Można zasadnie uznać, że stworzona przez Marcina Polaka tablica synchronistyczna była użyteczna w pracy tylko w przypadku wąskiej elity intelektualistów, pozostali zaś czytelnicy kroniki Marcina traktowali ją jako zwykły tekst narracyjny i dlatego chętnie rezygnowali z układu tabelarycznego. Tak więc, należy skonkludować, że podobnie jak w przypadku kroniki Euzebiusza/Hieronima, dzieło Marcina było wykorzystaniem obrazowej techniki graficznej w celu ułatwienia przeszukiwania tekstu, a nie stworzenia wizualizacji dziejów.

${ }^{24}$ Por. Karolina Grodziska-Ożóg, Marcin Polak i jego twórczość, „Nasza Przeszłość”, 58:1982, s. 169-201.

25 Problemy związane z tradycją rękopiśmienną i popularnością kroniki Marcina szczegółowo omawia A.-D. von den Brincken, Studien zur Überlieferung der Chronik Martins von Troppau, Teil 1, „Deutsches Archiv für Erforschung des Mittelalters”, 41:1985, s. 460-531, Teil 2, „Deutsches Archiv für Erforschung des Mittelalters”, 45:1989, s. $551-591$.

${ }^{26}$ Kraków, rps BJ, sygn. 304. Por. także J. Soszyński, Kronika Marcina Polaka i jej średniowieczna tradycja rękopiśmienna w Polsce, Warszawa 1995, „Studia Copernicana” t. XXXIV, s. 68-69. Miarę tego jak trudne w egzekucji pisarskiej, a następnie typograficznej, było odtwarzanie tablicy synchronistycznej Marcina Polaka najlepiej ilustruje fakt, że żadne z sześciu nowożytnych drukowanych wydań tego dzieła nie powtarza jej precyzyjnie, co więcej wydawcy nierzadko rezygnowali z niej całkowicie, rozbijając tekst na trzy następujące po sobie księgi, obejmujące kolejno dzieje przedchrystusowe, papieży i cesarzy (pełna bibliografia wydań drukowanych [w:] Marcin Polak, Kronika..., s. 74). 


\section{Werner Rolevinck}

$\mathrm{Z}$ potrzebami szerokiego kręgu czytelniczego należy powiązać trzeci z przywołanych na wstępie tekstów - Fasciculus temporum. Życiorys autora tego dzieła, Wernera Rolevincka, bynajmniej nie obfituje w wydarzenia $^{27}$. Urodził się on w $1425 \mathrm{r}$. w zamożnej rodzinie chłopskiej w okolicach Laer w Westfalii. Podstawy wykształcenia otrzymał w domu. W dwunastym roku życia opuścił stronny rodzinne, by się kształcić dalej i najprawdopodobniej trafił do Kolonii. W 1447 r. wstąpił do zakonu kartuzów. W kolońskiej kartuzji św. Barbary spędził przeszło pół wieku, zdobywając szerokie uznanie jako uczony i pisarz, autor licznych prac przede wszystkim o charakterze teologicznym ale także pism historycznych, moralizatorskich i pedagogicznych, z których sporo trafiło do druku. Zmarł w 1502 r.

Spośród wszystkich pism, które wyszły spod jego pióra, największą popularnością cieszył się Fasciculus temporum ${ }^{28}$. Praca ta po raz pierwszy została wydrukowana w Kolonii w 1474 r. i od razu okazała się wydarzeniem na rynku księgarskim. Za życia autora ukazało się przeszło trzydzieści wydań drukowanych ${ }^{29}$. Dopiero ok. 1532 r. Fasciculus temporum ustąpił pola nowszym pracom, chociaż co jakiś czas nadal był drukowany aż do XVIII w. Oryginał napisany po łacinie został przełożony na flamandzki, niemiecki i francuski. Jedno z wydań ukazało się nawet w odległej Sewilli (1480). Ostatnie wydanie wydrukowano w 1726 r.

27 Co się tyczy życiorysu Rolevincka, por. K. Colberg, Werner Rolevinck, [w:] Verfasserlevlexikon. Die dentsche Literatur des Mittelalter, wyd. II, t. 8, 1992, kol. 153-158.

${ }^{28}$ Jak dotychczas Fasciculus temporum nie doczekał się edycji krytycznej; wśród niezbyt licznych prac dotyczących rękopisów, wydań drukowanych i wybranych aspektów tego dzieła należy zwrócić uwagę na: Margaret Bingham Stillwell, The Fasciculus Temporum. A Genealogical Survey of Editions before 1480, [w:] Bibliographical Essays. A Tribute to Wilberforce Eames, Cambridge, Mass. 1924, s. 409-440; Frans A. Janssen, Author and Printer in the History of Typographical Design, „Quaerendo”, 21:1991, 1, s. 11-37; Laviece C. Ward, Authors and Authority: The Influence of Jean Gerson, and the „Devotio Moderna" on the «Fasciculus Temporum» of Werner Rolevinck, [w:] Die Kartäuser und Ihre Welt - Kontakte und Gegenseitige Einflüsse, t. 1, Salzburg 1993 (Analecta Carthusiana, 62), s. 171-188; taż, A Carthusian View of the Holy Roman Empire: Werner Rolevinck's 'Fasciculus Temporum', [w:] Die Kartäuser und das Römische Reich, t. 4, Salzburg 1999 (Analecta Carthusiana, 140), s. 23-44; taż, The Fasciculus Temporum and Early Printing in Spain, [w:] Scala Dei. Primera Cartoixa de la Peninsula Iberica i l'Ordre Cartoixa, [b.m.] 1999, (Analecta Cartusiana, 139), s. 347-362; taż, Werner Rolevinck and the Fasciculus Temporum, [w:] Gronigen 2002. Normative Zentrierung - Normative Centering, ed. by Rudolf Suntrup and Jan R. Veenstra (Kultureller Wandel vom Mittelalter zur Frühen Neuzeit - Medieval to Early Modern Culture, 2), Frankfurt am Main 2002, s. 209-30.

${ }^{29}$ Incunabula Poloniae odnotowują przeszło sto egzemplarzy (w tym utracone w czasie wojny) oryginału łacińskiego oraz kolejne kilkadziesiąt kopii przekładu niemieckiego. 
Fasciculus temporum, czyli „Zeszyt dziejów”, to kronika uniwersalna obejmująca historię ludzkości od stworzenia świata do drugiej połowy XV w. (różne wydania zawierają różne uzupełnienia, dociągające przegląd wydarzeń do chwili druku). Wykład Rolevincka zrywa z annalistyczną tradycją zapoczątkowaną przez kronikę Euzebiusza-Hieronima. Jego pomysł pogrupowania i rozplanowania graficznego treści wydaje się niezwykle nowoczesny. Przede wszystkim Rolevinck unika opowiadania. Posługuje się czymś, co porównać by należało z kapsułkami w dzisiejszych wielobarwnych publikacjach popularno-naukowych - zwięzłymi całostkami tekstowymi, ograniczonymi zazwyczaj do jednego, dwu zdań; w wyjątkowych przypadkach obejmujących zdań kilka.

Rozkładówka zaprojektowana przez Rolevincka odbiega od wcześniej stosowanych tablic porównawczych. We wcześniejszych kronikach uniwersalnych, odwołujących się do graficznych sposobów przekazu wiadomości, upływ czasu jest obrazowany pionowym schematem, biegnącym na kolejnych kartach lub rozkładówkach od góry w dół i synchronizującym równoległe kolumny w poziomie. Rolevinck czyni to inaczej: historia biegnie u niego od lewej do prawej, a synchronizacja odbywa się w pionie ${ }^{30}$. Rozkładówka dzieli się na pięć poziomych pasów: trzy z nich są szerokie i przedstawiają wydarzenia oraz postacie historyczne. Oddzielone są od siebie dwoma wąskimi paskami wyliczającymi lata według różnych systemów. Dla przejrzystości opisu szerokie pasy nazwijmy historycznymi (górny, środkowy i dolny), a wąskie - synchronizacyjnymi. Zacznijmy od pasków synchronizacyjnych, które stanowią kościec umożliwiający orientację chronologiczną i przesądzają o graficznej przejrzystości całej kroniki. Górny pasek wylicza w nieregularnych odstępach lata od stworzenia świata do 6673 roku. Pasek dolny (drukowany „do góry nogami”) liczy lata przed narodzeniem Chrystusa, a następnie od narodzenia Chrystusa. Rozpoczyna więc wyliczanie od roku 5199 p.n.e. i kończy na roku 1474

Górny i dolny pas historyczny przedstawiają postacie i wydarzenia historyczne. Górny, przed narodzeniem Chrystusa, wylicza królów żydowskich i wodzów rzymskich, dolny - kapłanów żydowskich i królów syryjskich. Po narodzinach Chrystusa pas górny obejmuje biogramy cesarzy rzymskich i ważniejsze wydarzenia historyczne, natomiast dolny zawiera

${ }^{30} \mathrm{~W}$ poniższym opisie posłużono się wydaniem [Köln], Heinrich Quentell, 1480, $2^{\circ}$; inne wydania wszelako dosyć wiernie powielają ten sam schemat; por. prezentowany w internecie inkunabuł [Köln]: Konrad [Winters], 8.XI.1476. 2 $2^{\circ}-$ http://dfg-viewer.de/show/?set[mets] $=$ http $\% 3 \mathrm{~A} \% 2 \mathrm{~F} \% 2 \mathrm{Fdaten}$.digitale-sammlungen.de $\% 2 \mathrm{~F} \sim \mathrm{db}$ $\% 2$ Fmets\%2Fbsb00031272_mets.xml [dostęp 10 grudnia 2011]. 
biogramy papieskie i dalszą porcję faktów historycznych. Środkowy pas historyczny do narodzin Chrystusa nosi nazwę „Linea Christi” i zawiera rozrysowanie graficzne rodowodu Jezusa zaczerpniętego z Ewangelii Mateusza (Mt 1,1). W dalszej części wypełniają go koła $\mathrm{z}$ wizerunkami i imionami kolejnych papieży. Oprócz uporządkowania chronologicznego według lat świata oraz przed i po narodzeniu Chrystusa, Rolevinck wkomponowuje w swą kronikę także schemat sześciu wieków ludzkości według św. Augustyna.

Charakterystyczny jest fakt, że Werner Rolevinck rezygnuje z precyzyjnego synchronizowania postaci i wydarzeń. Daty roczne, uwidocznione na paskach synchronizacyjnych są wyraźnie orientacyjne; nie sposób na ich podstawie dokonywać dokładnych ustaleń chronologicznych. Wskazuje to na fakt, iż autorowi przyświecał w jego pracy inny cel niż chęć dostarczenia uczonej pomocy encyklopedycznej. Kartuz Rolevinck pozostawał pod wpływem devotio moderna i pracę swą traktował, jako należącą do literatury budującej z elementem mistycznym ${ }^{31}$. O ile Rolevinckowi obca była chęć zadbania o potrzeby encyklopedyczne scholarów, o tyle całkiem nieobce było mu pragnienie wytworzenia $\mathrm{w}$ umyśle przeciętnego czytelnika właściwego, zgodnego z nauką chrześcijańską, obrazu dziejów. Zaprojektował więc graficzno-treściowy przekaz - wizualizację dziejów - która miała jednocześnie taki obraz przekazywać i dostarczać materiałów do kontemplowania boskiej wspaniałości na przykładzie dziejów Jego stworzenia. A że przy okazji lektura mogła posłużyć także ku wzbogaceniu erudycyjnemu czytelnika, to mu zupełnie nie przeszkadzało, wszak nauka mogła również być krokiem zbliżającym do Boga.

\section{Wnioski}

Przedstawione powyżej trzy różne kroniki uniwersalne wykazują cechy wspólne. Łączy je przede wszystkim postrzeganie historii jako dziejów zbawienia (historia święta). Poza tym wszystkie trzy odznaczają się kompilacyjnym charakterem i dążą do zsyntetyzowania grecko-rzymskiej i hebrajskiej tradycji historycznej. Co dla nas jest tutaj szczególnie ważne, wszystkie trzy wykorzystują, choć w różny sposób i w różnych ce-

${ }^{31}$ L.C. Ward, Authors and Authority: The Influence of Jean Gerson, and the „Devotio Moderna” on the «Fasciculus Temporum» of Werner Rolevinck, [w:] Die Kartäuser und Ihre Welt - Kontakte und Gegenseitige Einflüsse, ed. James Hogg, t. 1 (Analecta Carthusiana, 62), s. 171-188. 
lach, możliwości graficznego układu treści dla przekazywania czytelnikowi dodatkowych informacji pozatekstowych. Na tym jednak istotniejsze podobieństwa się kończą; katalog różnic jest znacznie szerszy, a także znacznie bardziej pouczający.

Euzebiusz z Cezarei był z pewnością tym autorem, który do historiografii chrześcijańskiej wprowadził element synchronizacyjny. Kronika Euzebiusza-Hieronima to potężne objętościowo dzieło, które w popularyzatorskim wydaniu dostępnym w Internecie liczy 332 strony. Historia porządkowana jest w nim w postaci tablicy, precyzyjnie synchronizującej wydarzenia i osoby przyporządkowane do różnych podmiotów historycznych (królestwa), które powstają i giną. Celem, który przyświecał Euzebiuszowi (a potem Hieronimowi), było wpisanie historii biblijnej w uznane dzieje świata grecko-rzymskiego, swoista legitymizacja intelektualna nowego elementu w cywilizacyjnej mozaice cesarstwa rzymskiego. Czy tablicę synchronistyczną Euzebiusza-Hieronima można jednak uznać za wizualizację historii? Odpowiedź na to pytanie jest negatywna. Prosta synchronizacja, bez względu na to czy tylko dwóch czy aż dziewięciu ciągów faktograficznych, nie jest jeszcze wizualizacją wiedzy. Jest to zaledwie zabieg techniczny, chociaż jest on krokiem w kierunku wizualizacji wiedzy.

Kronika Marcina Polaka, praca dużo bardziej zwięzła (skomprymowana tak bardzo, że w swej lakoniczności momentami aż niezrozumia$\mathrm{la}^{32}$ ), pozostaje przedstawicielem tej samej koncepcji myślowej, co dzieło Euzebiusza-Hieronima, od którego różni się tylko tym, że wielość podmiotów historycznych zastępuje dwoma. Natomiast podporządkowanie rozplanowania graficznego dychotomicznej wizji władz rządzących światem, a więc doktrynie ideologiczno-politycznej, jest tym, co czyni pracę Marcina Polaka bliższą wizualizacji wiedzy niż kronika Euzebiusza-Hieronima; bliższą, ale jeszcze nie wizualizacją. Układ graficzny Kroniki papieży $i$ cesarzy, za wyjątkiem elementu dychotomiczności w rozumieniu dziejów, nie jest pozatekstowym elementem informacyjnym sam w sobie (dzieło Marcina i bez rozplanowania tabelarycznego przekazuje tę samą wizję dziejów ${ }^{33}$ ); jest on nadal środkiem technicznym ułatwiającym porównanie chronologii obydwu ciągów historii.

\footnotetext{
32 Por. Marcin Polak, Kronika papieży i cesarzy..., s. 33-35.

${ }^{33}$ Część pierwsza kroniki kończy się passusem ideologicznym, explicite wykładającym doktrynę dwóch władz rządzących światem; por. Marcin Polak, Kronika papieży i cesa$r z y \ldots$, s. 227-228.
} 
O wizualizacji wiedzy możemy mówić dopiero w przypadku książki Wernera Rolevincka. Fasciculus temporum cechuje zwięzłość - całość zawarta jest na około 130 stronach luźnego druku. Encyklopedyczne cele, które z pewnością w jakiejś mierze także przyświecały autorowi, są jednak ograniczone przez odrzucenie precyzji synchronizowania i datowania postaci i wydarzeń. Ponieważ ważniejsza dla niego była motywacja mistyczna, sięgnął po poglądowość: rozplanowanie treści w ramach trzech równoległych ciągów historycznych, obrazujących nie tyle precyzyjną zgodność lub niezgodność chronologiczną co przybliżoną zbieżność czasową, jest niezależnym od samych treści, samodzielnym, pozatekstowym elementem przekazu. Tak więc Fasciculus temporum jest dziełem o charakterze mistyczno-dydaktycznym, które nie tyle ma służyć uczonym w ich intelektualnych dociekaniach, co pobudzać do refleksji religijnej, kontemplacji, i jednocześnie kształtować wizję historii uniwersalnej wśród szerszego ogółu. Jakkolwiek na przełomie XV i XVI wieku trudno mówić o masowym odbiorcy, to jednak trzydzieści wydań drukiem, które się pojawiły w ciągu niecałych sześćdziesięciu lat wzmożonej popularności dzieła, powoduje, iż w obieg musiało wejść co najmniej dziesięć tysięcy egzemplarzy kroniki. I można śmiało założyć, że zadecydował o tym znakomicie przez autora zastosowany komponent wizualizacyjny.

\section{Summary}

\section{From Synchronizing to Visualization: Methods of Presenting History in Medieval Universal Chronicles}

The article deals with the development of graphical systems of presenting history in universal chronicles on the instances of Eusebius of Caesarea and Jerome in late antiquity, Martinus Polonus in the thirteenth century, and Werner Rolevinck at the break of the Middle Ages and the Renaissance. With the translation of the Eusebius' Chronikoi Canones performed by Jerome, the synchronistic table was introduced into the Western historiographical tradition. This form of presenting history became firmly rooted in Latin chronicles, in particular within the genre of universal chronicles, which endeavoured to recount the history of mankind from Adam to the Final Judgement, and were very popular well into the early modern period. The author argues that the chronicles of Eusebius/Jerome and Martinus Polonus simply utilized synchronicity, in their pursuit to produce encyclopae- 
dic works, aimed at the scholarly reader. In their intention, the synchronistic table was a technical means for a more effective presentation of past events. With Werner Rolevinck the case was different. The layout introduced by him was no longer a synchronistic table, but an attempt at visualizing history, with very little attention paid to precise dating of various events and persons. He constructed his complicated graphical system for religious purposes, to contemplate the magnificence of God's creation, in accordance with the ideas of the devotio moderna, and destined his work for a much wider audience than scholars. 